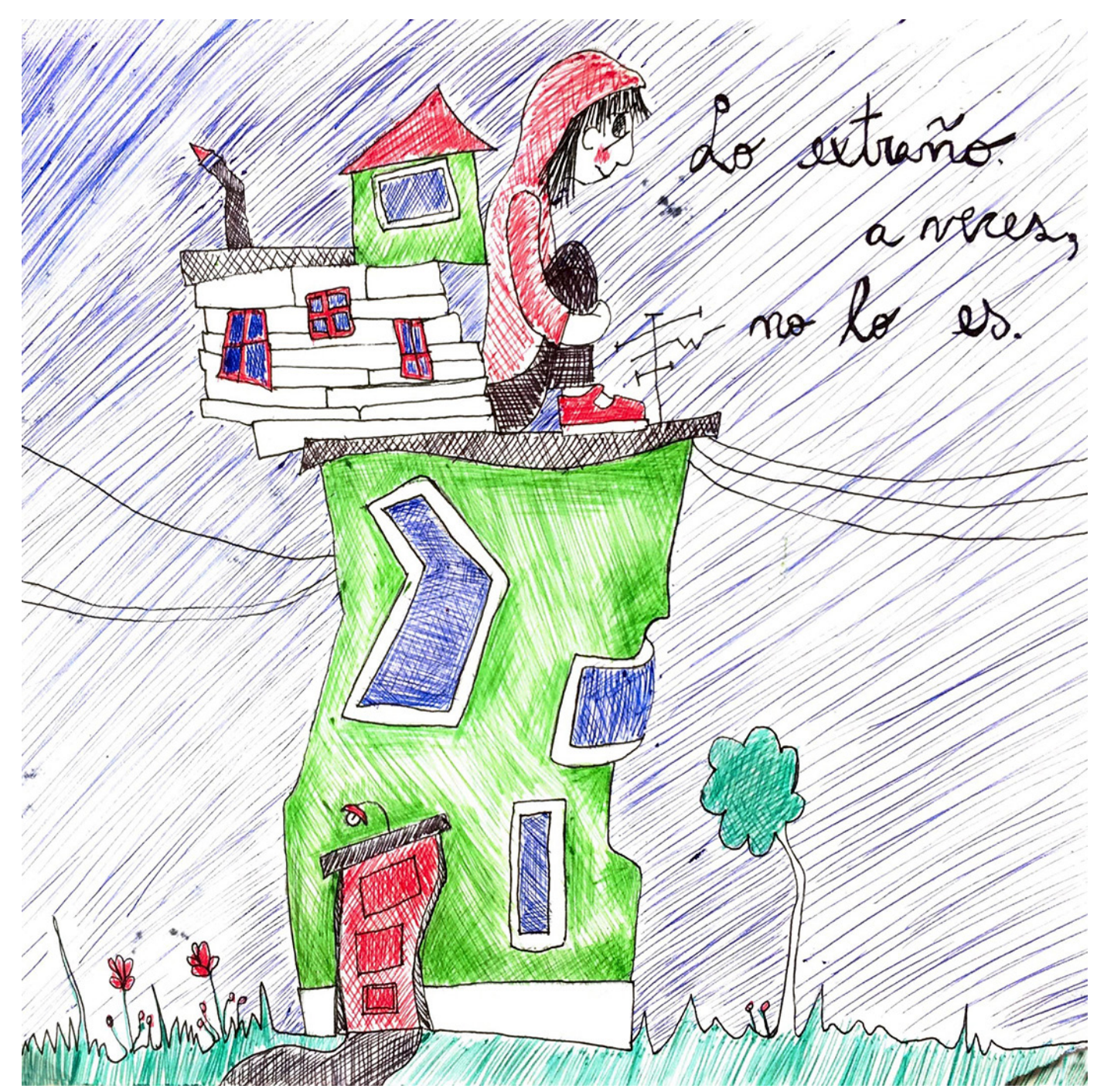

\title{
Lo extraño a veces, no lo es
}

\section{Técnica}

Bolígrafo de colores sobre papel fabriano.

\section{Reflexión}

Trata de cómo el cuerpo y la casa pasan a ser una sola cosa. Existen distintos espacios y materialidades dentro de un mismo espacio físico, así como sucede con la mente y emociones. Lo físico y psíquico se funden. "Lo extraño a veces, no lo es" Frase que dijo mi hija de 8 años al mirar el dibujo.

\section{Autora}

Daniela Lewin estudió la Especialización en Arte Terapia en la Universidad Nacional de las Artes de Buenos Aires. Trabajó dando clases de Arte con adultos donde fue una herramienta imprescindible para acercarse al proceso creativo de cada persona en el taller, a su imaginario y sus ritmos. También disfruta de la ilustración: Instagram Daniela Lewin dibus [@danielalewind].

Arteterapia: papeles de arteterapia y educación artística para la integración social. Monográfico: Las miradas del arte y el arteterapia en tiempos de la Covid19. ISSN-e: 1988-8309 https://dx.doi.org/10.5209/arte.75895 